the real obstacles to a renal transplantation programme, which should be rapidly expanding and for which there is such need. Such expansion will not occur until there is an improvement in the nursing establishment and medical junior staffing on the average acute medical or surgical ward, particularly in hospitals where the actual renal transplantation is not done.-I am, etc.,

JOHN GARFIELD

Wessex Neurological Centre,

Southampton General Hospital

\section{V.D. Statistics}

SIR,-When will producers of television programmes on Venereal Disease (B.B.C.2. 17 November), some of the participants, and unfortunately the authors of otherwise admirable papers (Dr. R. A. S. Wigfield, 6 November, p. 342) learn that statistics produced by venereal disease clinics can be most misleading unless explained? The figures widely quoted represent infections or conditions and not individual patients.

In the last few years the number of conditions recorded on the annual returns requested from the clinics by the Department of Health has increased considerably. Obviously if we increase the number of diseases recorded the figures must rise, and multiple infections, especially in womenthat is, gonorrhoea and trichomoniasis, or gonorrhoea and moniliasis, or all three, or even more all added to a grand total must inevitably give a distorted view of the overall picture. A quarter of a million registrations does not mean a quarter of a million people.

Surely the first thing we must do when dealing with such a highly emotive subject is to define our objectives. Do we want to disseminate knowledge or fear? The increase in gonococcal infections alone is bad enough without overstating the case even by inference, and it is difficult to see that exaggeration serves any useful purpose.-I am, etc.,

LESLIE WATT

Manchester Royal Infirmary,

Manchester

\section{Provision for the Mentally Handicapped}

SIR,-Campaign for the Mentally Handicapped is disturbed by some of the conclusions that Dr. D. C. Jones (13 November, p. 429) has drawn from his visit to services for the mentally handicapped in Denmark and Sweden. He says their hospitals are overstrained because parents are not anxious to accept their adult children home-even though social services in Sweden are extremely well organized-and concludes from this that "the majority of parents and relatives of patients still favour hospital care."

As an argument for retaining the present British hospital service for the mentally handicapped this is both disingenuous, and unfair to the Scandinavians, who have not only given us the only coherent principles of care for the handicapped we have to work from but are translating those principles into practice at a rate which puts us to shame. The Scandinavian principles of "normalization" demand that mentally handicapped people should be offered as nearly as possible the experiences and opportunities that the rest of us enjoy. This has led to a range of residential care in which the central homes Dr. Jones visited form only minor part. The main emphasis is increasingly on residential facilities in the mentally handicapped person's own locality, drawing on normal community provision for their services, and offering - as do the central residential homes-social and educational training rather than anything we would understand by "hospital care." An important secondary principle is that the adult mentally handicapped person should have the right to leave his family home and establish his own social context, just as we "normals" do.

Dr. Jones points out that the Scandinavians have not yet always provided the locally based residential facilities to make their principles practice. But he cannot in justice conclude from this that parents and relations prefer hospitals. The only poin that can fairly be made is that they opt for residential provision for their adult childas is their right, and his-and that hospital may be the only places which yet provide this. We know of no research in any country which shows that parents, given a free choice between small local homes which offer their child a continuing link with his community and a necessarily more distan hospital composed of a large number of mentally handicapped people, would opt for the latter.

It is important to establish this point. The Government's plans, in Better Services for the Mentally Handicapped, ${ }^{1}$ envisage a parallel development of locally based residential services by both hospital and local authorities. Campaign for the Mentally Handicapped believes that this dispersal of mentally handicapped people into the localities they belong to is the right pattern for the future. We are all aware that if the Scandinavian local residential services can be said to be inadequate, ours do not yet exist. If workers in the present hospital service seek to defend the existing pattern of residential care by drawing false conclusions from Scandinavian practice, the task ahead of us in establishing the new service is going to be made even harder than it need be.-I am, etc.,

\section{ANN SHEarer}

Campaign for the Mentally Hand:capped, 96 Portland Place,

1 Department of Health and Social Security (Welsh Office), Better Services for the Mentally
Handicapped. London, H.M.S.O., 1971.

\section{Pregnancy Testing}

SIR,-In your leading article on pregnancy testing (20 November, p. 444) you state, in reference to the home pregnancy test (Predictor) my company has just introduced, that a woman's belief she might be pregnant implies that she should have medical advice whether the result is positive or negative. In case your comment evolves from a belief that we are of a different opinion, I wish to draw to your attention the fact that we emphasize twice in the instruction leaflet not only that the woman's doctor should be consulted as soon as possible in the event of a positive result but also in the case of a negative result, of which we say: "If it (a repeat test) shows negative again, it is most unlikely that your missing period has anything to do with pregnancy. There may be other causes, however, and you are strongly advised to see your doctor for further investigation."-I am, etc.

A. B. Giles Marketing Manager,
Chefaro Proprietaries Ltd.

Morden, Surrey

\section{Prolonged Fever in Bacterial Meningitis}

SIR,-Early this year I wrote to you about this subject (15 May, p. 403). In that letter I stated that four sulphadiazine-resistant strains of Neisseria meningitidis had been examined and appeared to be related to serogroup 135.1 Subsequently our antiserum to the prototype strain of 135 was absorbed with a strain of $N$. meningitidis RAS 10 recently described ${ }^{2}$ to be nongroupable but a strain which cross-reacted with many antisera. This strain, in fact, did not react with any of our range of antisera except 135, with which it reacted very strongly. Following absorption of our antiserum it still reacted with the prototype strain of serogroup 135 but no longer reacted with the four strains I mentioned. Further examination of these strains, both in this laboratory and also by Dr. Harry Feldman of Syracuse, has shown them to belong to serogroup B.-I am, etc.,

Department of Pathology,

R. J. FALLON Ruchill Hospital,

Glasgow

Evans, J. R., Artenstein, M. S., and Hunter, D. H., Am8, 87, 643.

2 Devine, L. F.; and Hagerman, C. R., Infection and Immunity, 1970, 1, 226 .

\section{Caroli's Disease}

SIR,-The cases of focal congenital dilatations of the intrahepatic bile ducts described by J. Caroli et al..$^{1}$ differ from that described in the interesting report by Dr. M. J. Kelly (13 November, p. 407). Caroli's patients showed relatively normal extrahepatic bile ducts, quite different from choledochus cyst. The segmental intrahepatic duct dilatations were either superficial or deep within the liver parenchyma. Some contained areas of calcification. Jaundice in this disease may be due to ascending cholangitis or passage of a calculus into the common hepatic or common bile duct. Any patient with ascending cholangitis may develop intrahepatic abscesses which communicate with the bile ducts. In view of the long history of cholangitis in Dr. Kelly's patient it is possible that the intrahepatic duct dilatations demonstrated are related to abscess formation rather than true congenital dilatations.

Associated findings usually present in Caroli's disease, not mentioned by Dr. Kelly in his report, include hepatic fibrosis (usually present, according to Caroli) with portal hypertension, renal tubular dilatations resembling medullary sponge kidney, and undermineralization of the skeleton as in any patient with chronic liver disease. As Dr. Kelly mentioned, a choledochus cyst may involve one or more of the main hepatic ducts or the common bile duct. However, Caroli's disease and choledochus cyst are two different diseases with different radiological appearances. Caroli's disease may be 